\title{
Pregnancy and Renal Transplantation
}

\author{
Sepideh Khodaverdi, ${ }^{1,}$ Robabeh Mohammadbeigi, ${ }^{1}$ Mansoureh Vahdat, ${ }^{1}$ Shahla Mirgalooy Bayat, ${ }^{1}$ and \\ Maryam Khodaverdi ${ }^{2}$ \\ ${ }^{1}$ Endometriosis Research Center, Rasool-e-Akram Complex Hospital, Iran University of Medical Sciences, Tehran, Iran. \\ ${ }^{2}$ Department of Anesthesiology, Iran University of Medical Sciences, Tehran, Iran. \\ "Corresponding author: Sepideh Khodaverdi, Endometriosis Research Center, Rasool-e-Akram Complex Hospital, Niayesh Street, Sattar Khan Street, Tehran, Iran. Tel: \\ +98-2164352562, E-mail: sepidehkhodaverdi@yahoo.com
}

Received 2017 November 15; Revised 2018 January 27; Accepted 2018 March 07.

\begin{abstract}
Context: The current study aimed at providing an evidence - based and up-to-date review of the literature regarding the assessment and outcomes of pregnancy in patients with renal transplant.

Design: It was a review of the current literature.

Conclusions: According to the current study findings, the function or survival of renal allograft was not adversely affected by getting pregnant. Therefore, ideal care for these patients needs a multidisciplinary approach including maternal-fetal medicine, nephrology, and neonatology specialists.
\end{abstract}

Keywords: Abortion, Preeclampsia, Pregnancy, Preterm Labor, Renal Transplantation

\section{Introduction}

Although pregnancy in females with renal disease is increasingly observed, pregnancy in females undergoing dialysis is rare, and maternal and fetal morbidity and mortality are high under such circumstances $(1,2)$. Method of choice to treat the end - stage kidney disease and improve survival and quality of life in pregnant females with such complications is kidney transplantation (2). Restoration of pituitary - ovarian function and fertility in females is another benefit of this method (3); hence, it increases females' chance of becoming pregnant by approximately 4 - fold compared with dialysis (4-6). Murry et al., described the first cases of pregnancy in females with allograft kidney transplantation (7). According to the reported data, it is safe to get the conception 1 year after kidney transplantation (6-8). Since the function of allograft kidney, time between kidney transplantation and pregnancy, prescribed immunosuppression medication, and comorbid disease make such pregnancies risky (9), preconception counseling is needed to provide safety concerns for the mother, the infant, and the transplanted kidney.

Two major issues that arise in the first place by patients are: 1) The impact of pregnancy on transplanted kidney and 2) The outcome of pregnancy notwithstanding renal transplantation and medication intake.

\section{Methods}

The English scientific databases including Web of Science, PubMed, and Google Scholar as well as Persian databases such as SID, Magiran, and Iranmedex were searched from 1900 to 2015. The keywords searched in the current study were: [(kidney or renal) and transparent] and [pregnancy]. All papers regarding the outcomes of pregnancy patients with renal transplantation were enrolled.

\section{Results}

\subsection{The Effect of Pregnancy on Transplanted Kidney}

Although graft dysfunction and obstructive uropathy are reported in pregnant patients with kidney transplantation (9), studies compared the long - term outcomes of pregnancy on transplanted kidney with nulliparous transplanted controls did not show significant differences in the function or survival of graft in long term (10-17) (Table 1). Graft function in the 10 - year period was similar between patients with pregnancy history and controls (12-15). No significant differences are reported in the mean level of creatinine in pre- and post - pregnancy period, in many studies (12,18-20). Rosha et al., reported no differences between the median of estimated glomerular filtration rate 
(eGFR) before pregnancy and that of the time of follow - up at the last postpartum visits (17).

Serum creatinine before pregnancy could be a prognostic factor in the decline of kidney function with pregnancy as the patients with pre-pregnancy serum creatinine level $\geq 1.7 \mathrm{mg} / \mathrm{dL}$ had significant decline in renal function more often than the ones with normal baseline creatinine (20). As stated in the European best practice guidelines for renal transplantation, survival and graft function of such pregnant females, in the presence of normal graft function before pregnancy, is not worse (21).

\begin{tabular}{|c|c|c|}
\hline Author & Long - term Graft Survival & $\begin{array}{c}\text { Acute } \\
\text { Rejection \% }\end{array}$ \\
\hline Al Duraihimh et al. (19) & $\begin{array}{l}\text { Graft loss within } 2 \text { years of } \\
\text { delivery: } 0\end{array}$ & 2.9 \\
\hline Kashanizadeh et al. (11) & $\begin{array}{l}91 \% \text {, at } 5 \text {-year similar to the } \\
\text { controls }\end{array}$ & \\
\hline Gorgulu et al. (12) & $\begin{array}{l}\text { Similar to the controls at } 10 \\
\text { years }\end{array}$ & \\
\hline Gutierrez et al. (13) & $\begin{array}{l}\text { Similar to the controls at } 10 \\
\text { years }\end{array}$ & 0.0 \\
\hline Kim et al. (14) & $\begin{array}{l}\text { Similar to control group, } 78.5 \% \\
\text { at 10th year, } 67.3 \% \text { at } 15 \text { th year }\end{array}$ & \\
\hline $\begin{array}{l}\text { Pour - Reza - Gholi et al. } \\
\text { (15) }\end{array}$ & $\begin{array}{l}\text { Control group, } 94.5 \% \text { at } 5 \text { years } \\
\text { and } 77.1 \% \text { at } 10 \text { years }\end{array}$ & 6.7 \\
\hline Rahamimov et al. (10) & $\begin{array}{l}77.6 \% \text { at } 10 \text { years, } 61.6 \% \text { at } 15 \\
\text { years }\end{array}$ & 0.0 \\
\hline Bouattar et al. (18) & Graft loss within 59 months: 0 & 0.0 \\
\hline $\begin{array}{l}\text { Yassaee and Moshiri } \\
(22)\end{array}$ & Graft loss over 2 years: $3.2 \%$ & 2.1 \\
\hline Framarino et al. (23) & & 1.6 \\
\hline Pezeshki et al. (24) & & 11.0 \\
\hline Coscia et al. (NTPR) (25) & $\begin{array}{l}\text { Graft loss within } 2 \text { years of } \\
\text { delivery: } 8 \%-11 \%\end{array}$ & \\
\hline Sibanda et al. (26) & $\begin{array}{l}\text { Graft loss rate during } 2 \text { years of } \\
\text { delivery: } 6 \%\end{array}$ & \\
\hline Ghanem et al. (9) & & 0.0 \\
\hline Di Loreto et al. (27) & Graft loss at 2 years: 0 & 0.0 \\
\hline Bramham et al. (28) & & 2.0 \\
\hline Yildirim and Uslu (29) & $\begin{array}{l}\text { Graft loss within } 6 \text { months of } \\
\text { delivery: } 0\end{array}$ & 0.0 \\
\hline
\end{tabular}

\subsection{Fetal and Maternal Outcomes}

Two important factors affecting the pregnancy outcomes are the serum creatinine level prior to pregnancy and the interval between transplantation and pregnancy. Therefore, significant associations are reported between increased risk in cesarean section rate and short interval between pregnancy and allograft transplantation $(<2$ years) as well as preterm delivery and high serum creatinine level (> $1.5 \mathrm{mg} / \mathrm{dL}$ ) before pregnancy (29).

The overall live birth rate after kidney transplantation in the US is reported higher than that of general population: 73.5\% (95\% CI: 72.1 - 74.9) versus 66.7\% in a meta - analysis conducted on 3570 kidney transplant recipients (4). In other studies, live birth rate is reported $43.2 \%$ to $91 \%$ (Table 2).

The increased miscarriage rate after kidney transplantation is $14.0 \%$ and the rate of some adverse outcomes such as preeclampsia, preterm delivery, and delivery by cesarean section is more than that of normal population in such patients $(4,13,24,25)$.

Gestational diabetes, anemia, infection, graft dysfunction, graft pyelonephritis, de novo proteinuria $>1 \mathrm{~g} / \mathrm{d}$, and obstructive uropathy are other complications affecting such pregnancies $(9,17)$.

It is argued that the sole independent factor to prevent severe complications is the high glomerular filtration rate (GFR) before getting pregnant (2). Accordingly, diastolic blood pressure (BP) $>90 \mathrm{mmHg}$ in the second and third trimesters and serum creatinine level $>125 \mu \mathrm{M} / \mathrm{L}$ are considered potential predictive factors for poor pregnancy outcomes (28).

\section{Discussion}

As already noted, successful pregnancy is expected in the majority of females with transplanted kidney, but maternal and fetal complication rates are high.

The most common complications are pre - eclampsia, low birth weight, and premature birth both in reports from single centers and data from large pregnancy registries. It is argued that there are some reasons for high prevalence of complications in such patients:

1. Continuation of the underlying diseases resulting in kidney transplant and their effects on pregnancy outcomes (28).

2. As mentioned above, the function of transplanted kidney before pregnancy has a great impact on pregnancy complications $(2,28,29)$.

3. The immunosuppressive medications could contribute to the high pregnancy complication rate in the kidney transplanted cases $(31,32)$.

It was reported in some medications used by such patients that prednisone and cyclosporine can induce hypertension during pregnancy or exacerbate it and be subsequently followed by an increased risk of preeclampsia and 


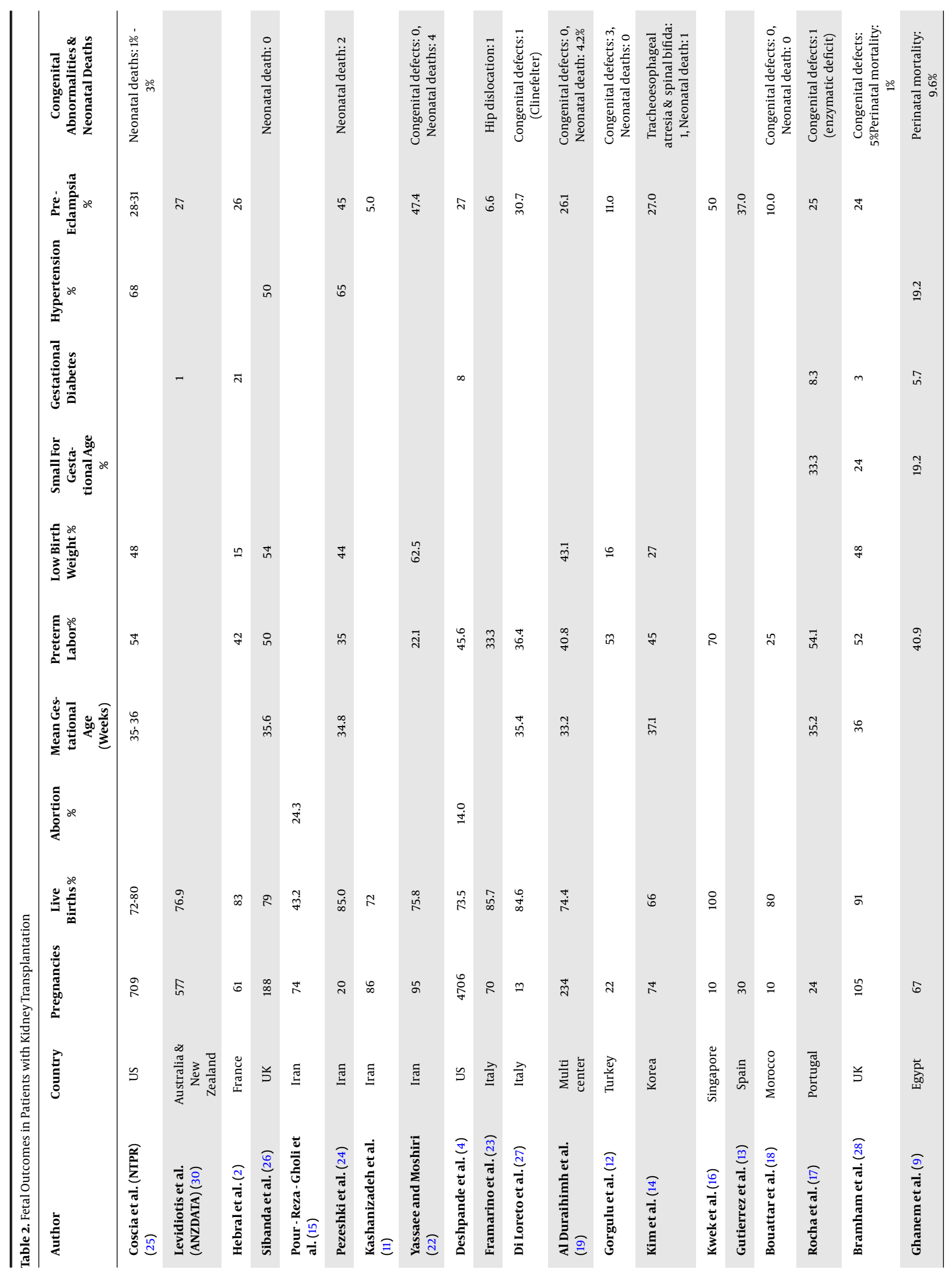


early delivery resulting from it $(31,32)$. Cyclosporine is also associated with low birth weight (25).

In a Meta - analysis, the incidence of gestational diabetes mellitus (GDM) in pregnant females with kidney transplants was $8 \%$ (4). It is assumed that diabetogenic effect of immunosuppressive drugs, especially prednisolone and tacrolimus that are used more frequently in patients with kidney transplantation, is the cause of increased incidence of $\operatorname{GDM}(2,28)$.

Cardiovascular disease along with diabetes is the common comorbidity in kidney transplant recipients and both could cause a high risk pregnancy in such patients and put their allograft at risk too. Furthermore, there are some other special factors including advanced maternal age, long - term exposure to high risk pharmacological medications, and previous abdominal surgery that increase the complications of their pregnancy (4).

It is observed that in high risk population the risk of preeclampsia could be reduced by taking aspirin (33). According to the current UK guidelines, it should be advised to all pregnant females with chronic kidney disease (CKD) to take aspirin during their pregnancy (34), despite its efficacy to prevent preeclampsia, it is never studied in females with kidney transplants.

The majority of high caesarean section rates in the ones undergoing kidney transplantation is attributed to fetal distress or maternal indications and many are performed preterm.

It seems that the incidence of prematurity and low birth weight is high in such pregnancies. Majority of females with kidney transplant have children with natural development and could achieve their normal height and weight; and their performance is usually appropriate in school $(35,36)$.

Data on graft survival are reassuring and the range of graft loss is $0 \%$ and $8.6 \%$ at 1 year following the pregnancy (37), but the important concern is high incidence of pregnancy complications in pregnant females with kidney transplant. Investigators consistently showed that pregnancy after renal transplantation generally has excellent graft survival. In 5 studies, long-term outcomes were compared between patients with kidney transplantation and a history of pregnancy and those of nulliparous as the control and no significant differences were observed in the graft function or survival (10-14). The reported survival rates were $61.6 \%$ to $84.8 \%$ in patients with a history of pregnancy versus $58.1 \%$ to $78.8 \%$ in the controls at the 15 - year follow-up $(10,14)$.

\section{Conclusions}

According to the current study findings, the function or survival of renal allograft was not adversely affected by pregnancy. Despite the fact that restoration of fertility after transplantation may alter the quality of life, obstetric and perinatal complications are increased in this population. It should be considered in consultation with these patients and decision making process and post - transplantation pregnancies should be managed in a tertiary center. Therefore, ideal care for these patients needs a multidisciplinary approach including maternal - fetal medicine, nephrology, and neonatology specialists.

\section{References}

1. Nevis IF, Reitsma A, Dominic A, McDonald S, Thabane L, Akl EA et al. Pregnancy outcomes in women with chronic kidney disease: a systematic review. Clin J Am Soc Nephrol. 2011;6(11):2587-98. doi: 10.2215/CJN.10841210. [PubMed: 21940842].

2. Hebral AL, Cointault O, Connan L, Congy-Jolivet N, Esposito L, Cardeau-Desangles I, et al. Pregnancy after kidney transplantation: outcome and anti-human leucocyte antigen alloimmunization risk. Nephrol Dial Transplant. 2014;29(9):1786-93. doi: 10.1093/ndt/gfu208. [PubMed: 24914091].

3. Yilmaz N, Yilmaz UE, Unal A, Unal E, Titiz I. Delivery in female kidney transplant recipients with hepatitis $C$ virus infection: is it safe for mother and newborn? Prog Transplant. 2012;22(2):141-4. 154. doi: 10.7182/pit2012667. [PubMed: 22878070].

4. Deshpande NA, James NT, Kucirka LM, Boyarsky BJ, Garonzik-Wang JM, Montgomery RA, et al. Pregnancy outcomes in kidney transplant recipients: a systematic review and meta-analysis. Am J Transplant. 2011;11(11):2388-404. doi: 10.1111/j.1600-6143.2011.03656.x. [PubMed: 21794084].

5. Watnick S. Pregnancy and contraceptive counseling of women with chronic kidney disease and kidney transplants. Adv Chronic Kidney Dis 2007;14(2):126-31. doi: 10.1053/j.ackd.2007.01.003. [PubMed: 17395115].

6. Davison JM, Bailey DJ. Pregnancy following renal transplantation. J Obstet Gynaecol Res. 2003;29(4):227-33. doi: 10.1046/j.13418076.2003.00106.x.

7. Murray JE, Reid DE, Harrison JH, Merrill JP. Successful pregnancies after human renal transplantation. N Engl J Med. 1963;269:341-3. doi: 10.1056/NEJM196308152690704. [PubMed: 13936776].

8. Jungers P, Chauveau D. Pregnancy in renal disease. Kidney Int. 1997;52(4):871-85. [PubMed: 9328925].

9. Ghanem ME, El-Baghdadi LA, Badawy AM, Bakr MA, Sobhe MA, Ghoneim MA. Pregnancy outcome after renal allograft transplantation: 15 years experience. Eur J Obstet Gynecol Reprod Biol. 2005;121(2):178-81. doi: 10.1016/j.ejogrb.2004.11.035. [PubMed: 16009483].

10. Rahamimov R, Ben-Haroush A, Wittenberg C, Mor E, Lustig S, Gafter $U$, et al. Pregnancy in renal transplant recipients: long-term effect on patient and graft survival. A single-center experience. Transplantation. 2006;81(5):660-4. doi: 10.1097/01.tp.0000166912.60006.3d. [PubMed: 16534465].

11. Kashanizadeh N, Nemati E, Sharifi-Bonab M, Moghani-Lankarani M, Ghazizadeh S, Einollahi B, et al. Impact of pregnancy on the outcome of kidney transplantation. Transplant Proc. 2007;39(4):1136-8. doi: 10.1016/j.transproceed.2007.03.010. [PubMed: 17524914].

12. Gorgulu N, Yelken B, Caliskan Y, Turkmen A, Sever MS. Does pregnancy increase graft loss in female renal allograft recipients? Clin Exp 
Nephrol. 2010;14(3):244-7. doi: 10.1007/s10157-009-0263-6. [PubMed: 20091332].

13. Gutierrez MJ, Gonzalez P, Delgado I, Gutierrez E, Gonzalez E, Siqueira $\mathrm{RC}$, et al. Renal allograft function and cardiovascular risk in recipients of kidney transplantation after successful pregnancy. Transplant Proc. 2009;41(6):2399-402. doi: 10.1016/j.transproceed.2009.06.042. [PubMed: 19715932].

14. Kim HW, Seok HJ, Kim TH, Han DJ, Yang WS, Park SK. The experience of pregnancy after renal transplantation: pregnancies even within postoperative 1 year may be tolerable. Transplantation. 2008;85(10):1412-9. doi: 10.1097/TP.ob013e318170f8ed. [PubMed: 18497680].

15. Pour-Reza-Gholi F, Nafar M, Farrokhi F, Entezari A, Taha N, Firouzan A et al. Pregnancy in kidney transplant recipients. Transplantation proceedings. 2005;37(7):3090-2. doi: 10.1016/j.transproceed.2005.08.033.

16. Kwek JL, Tey V, Yang L, Kanagalingam D, Kee T. Renal and obstetric outcomes in pregnancy after kidney transplantation: Twelve-year experience in a Singapore transplant center. J Obstet Gynaecol Res. 2015;41(9):1337-44. doi: 10.1111/jog.12736. [PubMed: 26017543].

17. Rocha A, Cardoso A, Malheiro J, Martins LS, Fonseca I, Braga J, et al. Pregnancy after kidney transplantation: graft, mother, and newborn complications. Transplant Proc. 2013;45(3):1088-91. doi 10.1016/j.transproceed.2013.02.006. [PubMed: 23622633].

18. Bouattar T, Hakim H, Rhou H, Benamar L, Bayahia R, Ouzeddoun N. Pregnancy in renal transplant recipients. Transplantation proceedings. 2009;41(5):1586-8. doi:10.1016/j.transproceed.2009.02.105.

19. Al Duraihimh H, Ghamdi G, Moussa D, Shaheen F, Mohsen N, Sharma $\mathrm{U}$, et al. Outcome of 234 pregnancies in 140 renal transplant recipients from five middle eastern countries. Transplantation. 2008;85(6):8403. doi: 10.1097/TP.ob013e318166ac45. [PubMed: 18360265].

20. Han D, Lee R, Kim T, Kim S, Kim S. Pregnancy after renal transplantation. Transplantation proceedings. 2000;32(7):1871-2. doi: 10.1016/S0041-1345(00)01470-6.

21. Ebpg Expert Group on Renal Transplantation . European best practice guidelines for renal transplantation. Section IV: Long-term management of the transplant recipient. IV.10. Pregnancy in renal transplant recipients. Nephrol Dial Transplant. 2002;17 Suppl 4:50-5. [PubMed: 12091650].

22. Yassaee F. O1026 Pregnancy outcome in kidney transplant patient. Int J Gynecol Obstet. 2009;107:S385. doi:10.1016/s0020-7292(09)61399-0.

23. Framarino Dei Malatesta M, Rossi M, Rocca B, Iappelli M, Poli L, Piccioni MG, et al. Fertility following solid organ transplantation. TransplantProc.2007;39(6):2001-4.doi:10.1016/j.transproceed.2007.05.014 [PubMed: 17692676].

24. Pezeshki M, Taherian AA, Gharavy M, Ledger WL. Menstrual characteristics and pregnancy in women after renal transplantation. Int J Gynaecol Obstet. 2004;85(2):119-25. doi: 10.1016/j.ijgo.2003.09.013. [PubMed: 15099772].
25. Coscia LA, Constantinescu S, Moritz MJ, Frank AM, Ramirez CB, Doria C, et al. Report from the National Transplantation Pregnancy Registry (NTPR): outcomes of pregnancy after transplantation. Clin Transpl. 2008:89-105. [PubMed: 19708448].

26. Sibanda N, Briggs JD, Davison JM, Johnson RJ, Rudge CJ. Pregnancy after organ transplantation: a report from the UK Transplant pregnancy registry. Transplantation. 2007;83(10):1301-7. doi: 10.1097/01.tp.0000263357.44975.do. [PubMed: 17519778].

27. Di Loreto P, Martino F, Chiaramonte S, Dissegna D, Ronco C, Marchesoni D, et al. Pregnancy after kidney transplantation: two transplantation centers-Vicenza-Udine experience. Transplant Proc. 2010;42(4):1158-61. doi: 10.1016/j.transproceed.2010.03.082. [PubMed: 20534249].

28. Bramham K, Nelson-Piercy C, Gao H, Pierce M, Bush N, Spark P, et al. Pregnancy in renal transplant recipients: a UK national cohort study. Clin J Am Soc Nephrol. 2013;8(2):290-8. doi: 10.2215/CJN.06170612. [PubMed: 23085724].

29. Yildirim Y, Uslu A. Pregnancy in patients with previous successful renal transplantation. Int J Gynaecol Obstet. 2005;90(3):198-202. doi: 10.1016/j.ijgo.2005.05.009. [PubMed: 16043182].

30. Levidiotis V, Chang S, McDonald S. Pregnancy and maternal outcomes among kidney transplant recipients. J Am Soc Nephrol. 2009;20(11):2433-40. doi: 10.1681/ASN.2008121241. [PubMed: 19797167].

31. Watnick S, Rueda J. Reproduction and contraception after kidney transplantation. Curr Opin Obstet Gynecol. 2008;20(3):308-12. doi: 10.1097/GCO.0b013e3282f8b009. [PubMed: 18460947].

32. Mastrobattista JM, Katz AR. Pregnancy after organ transplant. Obstet Gynecol Clin North Am. 2004;31(2):415-28. vii. doi: 10.1016/j.ogc.2004.03.005. [PubMed: 15200970].

33. Duley L, Henderson-Smart DJ, Knight M, King JF. Antiplatelet agents for preventing pre-eclampsia and its complications. Cochrane Database Syst Rev. 2004;(1). CD004659. doi: 10.1002/14651858.CD004659. [PubMed: 14974075].

34. National Institute for Health and Clinical Excellence. Hypertension in Pregnancy. The Management of Hypertensive Disorders During Pregnancy. London; 2010.

35. Sgro MD, Barozzino T, Mirghani HM, Sermer M, Moscato L, Akoury $\mathrm{H}$, et al. Pregnancy outcome post renal transplantation. Teratology. 2002;65(1):5-9. doi:10.1002/tera.1092. [PubMed:11835226].

36. Areia A, Galvao A, Pais MS, Freitas L, Moura P. Outcome of pregnancy in renal allograft recipients. Arch Gynecol Obstet. 2009;279(3):273-7. doi: 10.1007/s00404-008-0711-7. [PubMed: 18568355].

37. Richman K, Gohh R. Pregnancy after renal transplantation: a review of registry and single-center practices and outcomes. Nephrol Dial Transplant. 2012;27(9):3428-34. doi: 10.1093/ndt/gfs276. [PubMed: 22815546]. 